\title{
Does Motivational Music Influence Maximal Bench Press Strength and Strength Endurance?
}

\author{
Bereket KÖSE ${ }^{1}$ \\ 'Sirnak Üniversity, School of Pyhsical Education and Sports, Sirnak, Turkey \\ Email:bereket.kose@hotmail.com Tel:+905512491880
}

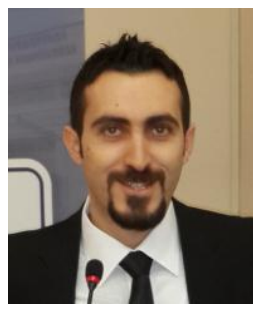

\begin{abstract}
The purpose of this study is to examine whether motivational music selected by participants has an effect on maximal bench press strength and strength endurance (number of repetitions to failure with a $60 \%$ of 1-RM). 26 healthy male students with an average age of $23.92 \pm 2.05$, average weight of $73.57 \pm 4.14$ and average height of $178.57 \pm 3.65$ who were having at least three strength workouts a week participated in the study voluntarily. The participants were grouped in two as experimental group and control group. The measurements of the experimental group were taken in two different sessions as with music and without music with 1 repetition maximum and number of repetitions to failure with $60 \%$ of 1 repetition maximum. The two sessions of the control group were conducted without music. At the end of the study, it was found that in experimental group motivational music was not effective on maximal strength $(1 \mathrm{RM})(\mathrm{p}>0.05)$, while it was found to increase strength endurance statistically by $3.9 \%(\mathrm{p}<0.05)$. In the control group, no statistically significant difference was found in both sessions $(p>0.05)$. As a conclusion, it is stated that listening to fast music creates an ergogenic acute effect and it is recommended to use music during strength workout to have a better strength endurance performance.
\end{abstract}

Keywords: Motivational music, Strength, Bench Press.

Citation | Bereket KÖSE (2018). Does Motivational Music Influence Maximal Bench Press Strength and Strength Endurance? Asian Journal of Education and Training, 4(3): 197-200. History:

Received: 25 April 2018

Revised: 16 May 2018

Accepted: 18 May 2018

Published. 21 May 9018

Licensed: This work is licensed under a Creative Commons

Attribution 3.0 License (cc)

Publisher:Asian Online Journal Publishing Group
Funding: This study received no specific financial support.

Competing Interests: The author declares that there are no conflicts of interests regarding the publication of this paper.

Transparency: The author confirms that the manuscript is an honest, accurate, and transparent account of the study was reported; that no vital features of the study have been omitted; and that any discrepancies from the study as planned have been explained.

Ethical: This study follows all ethical practices during writing.

\section{Contents}

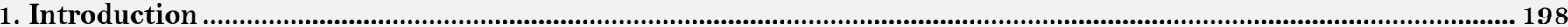

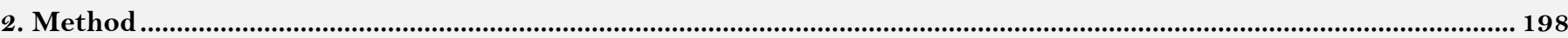

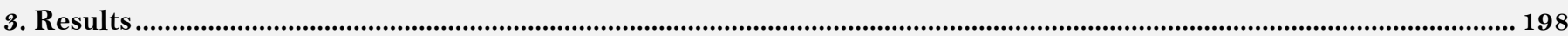

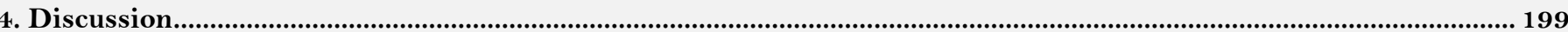

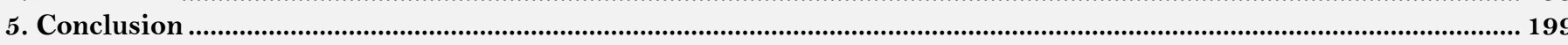

References 199 


\section{Introduction}

Music has been in people's lives for centuries and human beings have continually used music and are still continuing to use music in various ways. Music has sometimes been used to heal patients physically and mentally (Bally et al., 2003; Habibzadeh, 2011; Uyar and Akın, 2011) sometimes it has been used to encourage shopping customers to shop more (Radocy and Boyle, 2003) and sometimes it has been used to help people express their feelings to others (Somakçi, 2003). Recently, it has been shown by some authors that music develops physical performance, physiological parameters and moods of people who take exercise. Studies have reported that exercise with music positively influences rate of perceived exertion, increases running exhaustion time and positively influences participants psychologically and physiologically (Mohammadzadeh et al., 2008; Karageorghis et al., 2009; Thakur and Yardi, 2013). Terry et al. (2012) stated that motivational music increases exhaustion time while running by $18.1 \%$ when compared with no music. In addition, it has been found that mood is more positive in motivational music, exercise with music decreases $\mathrm{O}_{2}$ consumption with a rate of $1-7 \%$ and motivational music influences running economy better. Music needs to have some characteristics to be able to stimulate the person and influence exercise performance. Karageorghis et al. (1999) stated that it is important for musical rhythm, music type and harmony, cultural effect and musical tempo to be 120 beat per minute (bpm) and higher so that music can encourage effort. Studies conducted have generally examined the effect of music on cardiovascular performance and anaerobic performance; however, the effect of music on strength has been examined by a few researchers. Thus, the purpose of this study is to examine the effect of motivational music on maximal bench press strength and strength endurance.

\section{Method}

\subsection{Research Group}

26 healthy male students studying at Sirnak University with an average age of 23.92 2 2.05, average weight of $73.57 \pm 4.14$ and average height of $178.57 \pm 3.65$ who were having at least three strength workouts a week participated in the study voluntarily. The participants were randomly assigned in two as experimental group

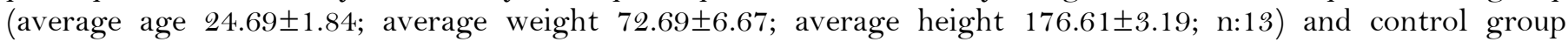

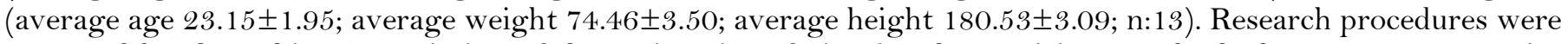
approved by the Ethics Commission of the University of Sirnak. The participants who had any upper extremity injuries were not included in the study. The participants were asked not to have intense workout, not to consume alcohol and supplements that can produce any ergogenic effects at least 48 hours before the measurements.

\subsection{Procedure}

Two measurements were performed on each group at the same hours of the day with one week in-between the measurements (Test 1 and Test 2). Experimental group performed the tests with and without music. Control group performed both tests without music. In the first measurements (Test 1) strength endurance (number of repetitions to failure with a $60 \%$ of $1-\mathrm{RM}$ ) of the control group was measured without music after 1 repetition maximum (1RM) and 5-minute long passive rest. In the experimental group, strength endurance (number of repetitions to failure with a $60 \%$ of $1-\mathrm{RM})$ and repetition maximum (1RM) were found by dividing the group in two as with music and without music in Test 1 in order to prevent learning. One week later (Test 2), 1RM and strength endurance measurements of the control group were made again with no music. In the experimental group, the participants whose measurements were taken with music in Test 1 did not listen to music, while those whose measurements were taken without music in Test 1 listened to music. The participants participated in the tests with the motivational music they selected and the group that listened to music continued to listen to music with music players and ear phones from the warm-up period until the measurements ended. Beats of the music (tempo) were adjusted as $>120$ bpm as recommended by Terry and Karageorghis (2011). According to this, it is emphasized that music with 120 and higher bpm, strong beats, obvious sound flow and rhythmical characteristics motivates and activates the individual (Terry and Karageorghis, 2011). The music used in the study was adjusted between $135-140$ bpm in order to standardize all the music.

\subsection{Measurements}

In the first session (Test 1), the participants first had a light run of 10 minutes on the treadmill by listening to music they selected and after this, they had 5 minutes of static and dynamic stretching. Later, the participants performed bench press to familiarize with lower loads. 1 repetition maximum (1RM) and strength endurance test (60\% of $1 \mathrm{RM})$ were found according to NSCA guidelines. While measuring 1RM bench press and strength endurance, the participants lied back with their heads, shoulders and hips on the sitting bench and legs touching the ground. The arms gripped the bar a bit wider than the shoulder width and for safety purposes, one person accompanied with the descending and ascending bar. For the start position, the participants lowered the bar to the point that could touch their chest and continued to lift until the elbows came to the full extension position. During the movement, the participant's head, shoulder and hip continued to touch the sitting bench (Miller and Conditioning Association, 2012).

\subsection{Statistical Analysis}

Statistical analysis was performed with SPSS-20 version. Kolmogorov-Smirnov test was conducted to find out whether the data were normally distributed. Paired Sample t-Test was conducted to measure the differences between the groups. $\mathrm{p}<0.05$ confidence interval was used for statistical procedures.

\section{Results}

Table 1 shows the $1 \mathrm{RM}$ and strength endurance (number of repetitions to failure with a $60 \%$ of $1-\mathrm{RM}$ ) of the experimental and the control group. It was found that listening to motivational music influenced $60 \%$ of $1 \mathrm{RM}$ statistically better in the experimental group when compared with no music state $(p<0.05)$. However, listening to music does not influence maximal strength $(\mathrm{p}>0.05)$. In the control group, the measurements of the participants 
were made in Test 1 and Test 2 without listening to music and in both sessions, no statistical changes were found in $1 \mathrm{RM}$ and $60 \%$ of $1 \mathrm{RM}(\mathrm{p}>0.05)$.

Table-1.1.Maximal strength and 60\% of maximal strength and Bench Press performance values of the experimental and control group

\begin{tabular}{|c|c|c|c|}
\hline & Test 1 & Test 2 & \multirow{2}{*}{$\mathbf{P}$} \\
\hline & Mean \pm SD & Mean \pm SD & \\
\hline \multicolumn{4}{|c|}{ Experimental group; n:13 } \\
\hline $\begin{array}{l}1 \mathrm{RM}(\mathrm{kg}) \\
60 \% \text { of } 1 \mathrm{RM}\end{array}$ & $\begin{array}{l}67.44 \pm 2.61 \\
21.84 \pm 0.98\end{array}$ & $\begin{array}{l}67.61 \pm 2.57 \\
22.69 \pm 1.18\end{array}$ & $\begin{array}{l}0.304 \\
0.005^{*}\end{array}$ \\
\hline \multicolumn{4}{|c|}{ Control group; n:13 } \\
\hline $\begin{array}{l}1 \mathrm{RM}(\mathrm{kg}) \\
60 \% \text { of } 1 \mathrm{RM}\end{array}$ & $\begin{array}{r}70.11 \pm 5.30 \\
20.38 \pm 1.38\end{array}$ & $\begin{array}{c}70.46 \pm 5.44 \\
20.61 \pm 1.44\end{array}$ & $\begin{array}{l}0.121 \\
0.427\end{array}$ \\
\hline
\end{tabular}

\section{Discussion}

A great number of studies conducted in literature have examined the effect of different types and tempo of music on endurance performance and anaerobic capacity, while a few studies have researched the influence of music on strength and strength endurance. The purpose of this study is to research the influence of participants' listening to motivational music they selected during workout on maximal strength and strength endurance and to contribute to literature.

This study conducted found that listening to music before and during exercise did not increase maximal strength. Some researchers predict that the reason why music does not increase maximal strength can be that music does not have an influence in maximal strength and that there is no rhythmical compound in one repetition at high load. Another reason predicted to decrease the effect of music on performance is the maximum intensity of 1RM test (Simpson and Karageorghis, 2006; Bateman and Bale, 2008; Bartolomei et al., 2015). Some researchers state that when work load is too high, the individual's attention is directed to the painful effects of effort and since the attention is not focused on music, the individual cannot make use of music during exercise (as cited in: Waterhouse et al. (2010)). In loads with maximal strength or close to maximal strength, the organism gets under stress due to the load on the organism and the central nervous system gives all its attention to overcome this load in order to overcome the stress. As a result of this, it is predicted that music does not increase performance during maximal exercise since the brain cannot pay attention to music.

An interesting result of this study is that motivational music increases strength endurance (bench press repetitions to failure with $60 \%$ of $1 \mathrm{RM}$ ) by $3.9 \%$. In a similar study, Bartolomei et al. (2015) found that music did not influence maximal strength but increased strength endurance by $5.8 \%$. Crust (2004) reported that listening to music during strength workout would ensure higher muscle endurance and on the contrary to listening to music before exercise, listening to music during the whole workout increased strength endurance time. Karageorghis et al. (1996) reported that motivational music created a positive effect on grip strength. Unlike these studies, Biagini et al. (2012) reported that music selected by participants did not increase performance in bench press strength endurance. In our study, the participants started to listen to self-selected motivational music and they continued to listen to this music during exercise because starting to listen to music before exercise simulates individuals and helps to motivate them. Studies conducted have reported that starting to listen to motivational music with warm up before starting to exercise increased strength endurance time and short term maximal performance (Crust, 2004; Chtourou et al., 2012). Listening to self-selected music with exercise was reported to increase performance when compared with listening to non self-selected music (Nakamura et al., 2010). Thus, it is recommended that in order to increase performance, athletes and individuals who have exercise should listen to self-selected music during the exercise session starting from the warm up.

\section{Conclusion}

In this study conducted, acutely $3.9 \%$ increase occurred in strength endurance $(60 \%$ of $1 \mathrm{RM})$ as a result of participants' listening to self-selected motivational music. As a conclusion, it is stated that listening to fast (motivational) music creates an ergogenic acute effect and it is recommended to use music during strength workout to have better strength endurance performance.

\section{References}

Bally, K., D. Campbell, K. Chesnick and J.E. Tranmer, 2003. Effects of patient-controlled music therapy during coronary angiography on procedural pain and anxiety distress syndrome. Critical Care Nurse, 23(2): 50-57. View at Google Scholar

Bartolomei, S., R.D. Michele and F. Merni, 2015. Effects of self-selected music on maximal Bench Press strength and strength endurance. Perceptual And Motor Skills, 120(3): 714-721. View at Google Scholar | View at Publisher

Bateman, A. and J. Bale, 2008. Sporting sounds: Relationships between sport and music. Routledge.

Biagini, M.S., L.E. Brown, J.W. Coburn, D.A. Judelson, T.A. Statler, M. Bottaro and N.A. Longo, 2012. Effects of self-selected music on strength, explosiveness, and mood. Journal of Strength \& Conditioning Research, 26(7): 1934-1938. View at Google Scholar $\mid$ View at Publisher

Chtourou, H., M. Jarraya, A. Aloui, O. Hammouda and N. Souissi, 2012. The effects of music during warm-up on anaerobic performances of young sprinters. Science \& Sports, 27(6): e85-e88. View at Google Scholar | View at Publisher

Crust, L., 2004. Carry-over effects of music in an İsometric muscular endurance task. Perceptual and Motor Skills, 98(3): 985-991. View at Google Scholar | View at Publisher

Habibzadeh, N., 2011. Does walking exercise İmprove bone mineral density of young obese and thin women? Nigerian Journal of Orthopaedics and Trauma, 10(1): 32-37. View at Google Scholar $\mid$ View at Publisher

Karageorghis, C.I., K.M. Drew and P.C. Terry, 1996. Effects of pretest stimulative and sedative music on grip strength. Perceptual and Motor Skills, 83(3_suppl): 1347-1352. View at Google Scholar | View at Publisher 
Karageorghis, C.I., D.A. Mouzourides, D.L. Priest, T.A. Sasso, D.J. Morrish and C.L. Walley, 2009. Psychophysical and ergogen ic effects of synchronous music during treadmill walking. Journal of Sport and Exercise Psychology, 31(1): 18-36. View at Google Scholar $\mid$ View at Publisher

Karageorghis, C.I., P.C. Terry and A.M. Lane, 1999. Development and İnitial validation of an İnstrument to assess the motivational qualities of music in exercise and sport: The brunel music rating inventory. Journal of Sports Sciences, 17(9): 713-724. View at Google Scholar 1 View at Publisher

Miller, T. and Conditioning Association, 2012. NSCA's guide to tests and assessments. Human Kinetics.

Mohammadzadeh, H., B. Tartibiyan and A. Ahmadi, 2008. The effects of music on the perceived exertion rate and performance of trained and untrained İndividuals during progressive exercise. Facta Universitatis-Series: Physical Education and Sport, 6(1): 67-74. View at
Google Scholar

Nakamura, P.M., G. Pereira, C.B. Papini, F.Y. Nakamura and E. Kokubun, 2010. Effects of preferred and nonpreferred music on continuous cycling exercise performance. Perceptual and Motor Skills, 110(1): 257-264. View at Google Scholar | View at Publisher

Radocy, R.E. and J.D. Boyle, 2003. Psychological foundation of music behavior. 4th Edn., Springfield: Charles C. Thomas.

Simpson, S.D. and C.I. Karageorghis, 2006. The effects of synchronous music on 400-M sprint performance. Journal of Sports Sciences, 24(10): 1095-1 102. View at Google Scholar | View at Publisher

Somakçi, P., 2003. Music therapy in Turks. Erciyes University Journal of Social Sciences, 15(12): 131-140.

Terry, P.C. and C.I. Karageorghis, 2011. Music in sport and exercise. In T. Morris \& P.C. Terry (Eds.), The new sport and exercise psychology companion morgantown. WV: Fitness Information Technology. pp: 359-380.

Terry, P.C., C.I. Karageorghis, A.M. Saha and S. D'Auria, 2012. Effects of synchronous music on treadmill running among elite triathletes. Journal of Science and Medicine in Sport, 15(1): 52-57. View at Google Scholar $\mid$ View at Publisher

Thakur, A.M. and S.S. Yardi, 2013. Effect of different types of music on exercise performance in normal individuals. Indian Journal of Physiology and Pharmacology, 57(4): 448-445. View at Google Scholar

Uyar, M. and K.E. Akın, 2011. The effect of music therapy on pain and anxiety in intensive care patients. Pain, 23(4): 139-146. View at Google Scholar

Waterhouse, J., P. Hudson and B. Edwards, 2010. Effects of music tempo upon submaximal cycling performance. Scandinavian Journal of Medicine \& Science in Sports, 20(4): 662-669. View at Google Scholar $\mid$ View at Publisher 